\title{
PROFIL AROMA DAN MUTU SENSORI CITARASA PASTA KAKAO UNGGULAN DARI BEBERAPA DAERAH DI INDONESIA
}

\author{
[Aroma and Flavor Sensory Profiles of Superior Cocoa Liquors \\ from Different Regions in Indonesia]
}

\author{
Intan Kusumaningrum ${ }^{1)^{*}}$, C. Hanny Wijaya2), Feri Kusnandar ${ }^{2)}$, Misnawi ${ }^{3)}$ dan Ariza Budi Tunjung Sari3) \\ 1) Program Studi Magister Ilmu Pangan, Institut Pertanian Bogor, Bogor \\ 2) Departemen IImu dan Teknologi Pangan, Fakultas Teknologi Pertanian, Institut Pertanian Bogor, Bogor \\ 3) Pusat Penelitian Kopi dan Kakao Indonesia, Jember
}

Diterima 12 Desember 2013 / Disetujui 06 Mei 2014

\begin{abstract}
The objective of this research was to compare the aroma profiles and flavor sensory qualities of three cocoa liquors obtained from different regions in Indonesia, namely East Java, South Sulawesi and Bali. The Ghanaian cocoa liquor was used as the reference. The aroma of cocoa liquors was extracted by using a Solid Phase Microextraction (SPME), followed by detection with Gas Chromatography-Mass Spectrometry/Olfactometry (GC-MS/O) with the Nassal Impact Frequency (NIF) method. A total of 28 aroma active compounds in the cocoa liquors were identified, where in 21, 19, 22 and 18 compounds were detected in East Java, Bali, South Sulawesi and Ghana liquors, respectively. The profiles of these three liquors were not only different from one another but were also different from the reference. East Java liquor had a specific aroma of strong chocolate, enriched with creamy, caramel and coffee bean aroma, whileBali liquor was dominated by creamy, caramel and sweet, and South Sulawesi liquor was specified by its sweet green aroma. The aroma sensory characteristic was evaluated by descriptive test, presenting the aroma of nutty, acid, caramel, earthy and chocolate, while the taste sensory attributes included astringency, bitterness and acidity. The sensory profile analysis was carried out by applying a Quantitative Descriptive Analysis (QDA) method. Accompired with preference and ranking tests were also conducted. Among the three cocoa liquors, the sensory profile of South Sulawesi was the most similar to that of Ghanaian cocoa liquor. However, the cocoa liquor from Bali and East Java cocoa were more preferred comparing to the liquor from South Sulawesi.
\end{abstract}

Keywords: aroma profile, cocoa bean, cocoa liquor, Gas Chromatography-Mass Spectrometry/Olfactometry (GC-MS/O), sensory profiles

\begin{abstract}
ABSTRAK
Penelitian ini bertujuan untuk membandingkan profil aroma dan mutu sensori pasta kakao dari tiga daerah di Indonesia yaitu dari Jawa Timur, Sulawesi Selatan dan Bali, dengan pasta kakao dari Ghana sebagai pembanding. Aroma pasta kakao diekstrak menggunakan Solid Phase Microextraction (SPME) yang dilanjutkan dengan identifikasi senyawa penyusunnya menggunakan Gas Chromatography-Mass Spectrometry/ Olfactometry (GC-MS/O) dengan metode Nassal Impact Frequency (NIF). Total sejumlah 28 komponen aroma aktif terindentifkasi pada ke empat pasta kakao, dengan masing-masing 21,19, 22 dan 18 komponen pada pasta kakao dari Jawa Timur, Bali, Sulawesi Selatan dan Ghana. Ketiga kakao unggulan memiliki profil aroma yang berbeda satu sama lain dan berbeda dengan profil aroma kakao Ghana. Pasta kakao Jawa Timur memiliki aroma yang khas, yaitu aroma chocolate yang kuat, creamy, caramel dan coffee bean. Pasta kakao Bali memiliki aroma creamy, caramel dan sweet. Adapun, pasta kakao Sulawesi Selatan memiliki aroma khas sweet green. Analisis sensori yang dilakukan meliputi Quantitative Descriptive Analysis (QDA), uji hedonik dan uji rangking. Atribut sensori aroma yang dihasilkan dari uji deskriptif adalah nutty, acid, caramel, earthy, chocolate, sedangkan atribut sensori rasa adalah astringency, bitterness dan acidity. Pasta kakao Sulawesi Selatan memiliki profil aroma dan rasa yang paling serupa dengan pasta kakao pembanding (Ghana). Hasil uji kesukaan dan uji rangking menunjukkan bahwa pasta kakao Bali dan Jawa Timur lebih disukai panelis dibandingkan dengan pasta kakao dari Sulawesi Selatan.
\end{abstract}

Kata kunci: biji kakao, Gas Chromatography-Mas Spectrometry/Olfactometry (GC-MS/O), pasta kakao, profil aroma, profil sensori

\section{PENDAHULUAN}

Kakao merupakan salah satu komoditi unggulan utama Indonesia yang memberikan kontribusi bagi penerimaan negara di sektor pertanian. Saat ini Indonesia menjadi negara pengekspor biji kakao terbesar ketiga di dunia setelah Pantai Gading dan Ghana, dengan produksi per tahun mencapai 530 ribu ton, yang setara dengan $13.6 \%$ produksi dunia (ICCO, 2013).

*Penulis Korespondensi:

Email: intan_kusumaningrum@yahoo.co.id
Biji kakao yang dihasilkan di Indonesia sebagian besar adalah biji kakao lindak (bulk) dan hanya sedikit perkebunan yang menghasilkan biji kakao mulia (edel). Sulawesi Selatan adalah penghasil biji kakao bulk terbesar yang mencapai $70 \%$ dari seluruh hasil produksi Indonesia (Langkong et al. 2011). Provinsi Bali merupakan salah satu di antara daerah lain penghasil kakao nasional (Dinas Perkebunan Provinsi Bali, 2012). Kakao edel atau dikenal juga dengan istilah "Java cocoa a light breaking" merupakan klon unggulan kakao Indonesia yang di- 
tanam secara luas di perkebunan-perkebunan di Jawa Tengah dan Jawa Timur (Direktorat Jenderal Perkebunan, 2012).

Karakteristik produk cokelat yang berkualitas sangat ditentukan oleh bahan dasar kakao. Mutu citarasa kakao dapat diketahui dengan profil pasta kakao. Profil kakao dapat diperoleh dengan melakukan analisis komponen aroma aktif pada pasta kakao dengan Gas Chromatography-Mass Spectrometryl Olfactometry (GC-MS/O), serta uji mutu sensori aroma dan rasa pasta kakao dengan menerapkan metode Quantitative Descriptive Analysis (QDA).

Misnawi dan Ariza (2011) menggunakan Solid Phase Microextraction (SPME) sebagai metode ekstraksi dan mampu mendeteksi profil aroma pasta kakao dengan GC-MS/O. Secara umum pasta kakao memiliki aroma manis, kacang, karamel, cokelat dengan senyawa-senyawa penciri (aroma active compounds) seperti trimetilpirazin, tetrametilpirazin, 2.3butanediol, asam dodekanoida, feniletil alkohol, etanon, benzen asetaldehida dan 1.4-bis (morfolinoasetil) piperazin, serta memiliki aroma asap (benzen asetaldehida, alfaetiliden).

Kualitas dan karakteristik sensori pasta kakao yang unggul, terutama yang terkait aspek profil rasa dan aroma (flavor) belum banyak dilakukan di Indonesia. Pemetaan profil pasta kakao pada berbagai daerah di Indonesia khususnya dari segi profil aroma dapat digunakan untuk memantau keunggulan biji kakao dari tiap daerah sehingga dapat lebih efektif dalam pemanfaatan dan pengembangannya di masa depan. Tujuan penelitian ini adalah untuk menelisik keunggulan pasta kakao dari Sulawesi Selatan, Jawa Timur dan Bali, dengan pembanding pasta kakao dari Ghana dengan mengidentifikasi komponen aroma aktif dari pasta kakao tersebut dengan menggunakan GC-MS/O, memetakan profil sensori dengan metode quantitative descriptive analysis (QDA), dan mengevaluasi hubungan antara profil sensori aroma pasta kakao tersebut dengan penerimaan sensori.

\section{BAHAN DAN METODE}

\section{Bahan}

Bahan yang digunakan adalah biji kakao terfermentasi yang diperoleh dari tiga daerah di Indonesia, yaitu Sulawesi Selatan (kakao bulk dari perkebunan rakyat di Luwu), Jawa Timur (kakao edel dari PT. Perkebunan Nusantara XII, Jember) dan Bali (kakao bulk dari perkebunan rakyat di Jembrana). Biji kakao dari Ghana (kakao bulk yang diperoleh dari PT. General Food Indonesia) digunakan sebagai pembanding. Flavor standar yang digunakan di antaranya adalah 2-metil pirazin, fenil etil alkohol, 2.3-pentandion yang diperoleh dari PT. Ogawa Indonesia, sedangkan flavor standar menggunakan etil butirat, cis-3 heksenon, fenil asetaldehid, 1-okten-3-ol (PT. Firmenich Indonesia), aldehid C33 (PT. Indesso Niagatama) dan asam asetat. Standar internal yang digunakan adalah dekana (PT. Sigma Aldrich).

\section{Pembuatan pasta kakao}

Sebanyak $500 \mathrm{~g}$ biji kakao dari ke empat daerah tersebut dikupas secara manual untuk memisahkan keping biji (kotiledon) dan kulitnya. Selanjutnya keping biji kakao disangrai pada suhu $120^{\circ} \mathrm{C}$ selama 12 menit. Keping biji hasil penyangraian kemudian dihancurkan dengan blender, dan selanjutnya dihaluskan dengan alat pemasta selama 15 menit (Misnawi dan Ariza, 2011). Pasta kakao kemudian dikemas dan disimpan pada suhu $5^{\circ} \mathrm{C}$.

\section{Analisis dengan GC-MS/O (modifikasi metode Misnawi dan Ariza, 2011)}

Analisis dengan GC-MS/O dimodifikasi dari Misnawi dan Ariza (2011) dimana ditambahkan tahapan identifikasi dengan menggunakan metode Nassal Impact Frequency (NIF) (Wijaya et al. 2005). Komponen aroma dari pasta kakao diekstrak dengan Solid Phase Microextraction (SPME), Serat penjerap (absorber) yang digunakan adalah Polydimethylsyloxanedivinilbenzena (PDMS-DVB) polimer (Supelco, USA). Standar internal yang digunakan adalah dekana dari PT. Sigma Aldrich. Pasta kakao ditimbang sebanyak $2 \mathrm{~g}$ ditempatkan pada vial berkapasitas $40 \mathrm{~mL}$. Selanjutnya vial dipanaskan dengan penangas air pada suhu $60^{\circ} \mathrm{C}$ sampai mencair. Standar dekana ditambahkan sebagai internal standar sebelum dilakukan ekstraksi. Kuantitas komponen volatil ditentukan dengan cara membandingkan luas area peak komponen dengan peak standar internal. Dilakukan sebanyak dua kali ulangan.

Hasil ekstraksi kemudian dianalisis menggunakan GC-MS/O (GC 7890 dan 5975 C) yang dilengkapi dengan split-splitless injektor yang diatur pada suhu $260^{\circ} \mathrm{C}$, Agilent Technologies GC system, Double Axis, USA. Kolom yang digunakan adalah DBFFAP dengan diameter dalam $0.25 \mathrm{~mm}$, panjang $30 \mathrm{~m}$, dan ketebalan $0.25 \mu \mathrm{m}$. Suhu detektor MS diatur pada suhu $280^{\circ} \mathrm{C}$. GC-MS/O diprogram pada suhu awal $40^{\circ} \mathrm{C}$ selama 5 menit, kemudian dinaikkan sampai $60^{\circ} \mathrm{C}$ selama 5 menit dan dinaikkan kembali $220^{\circ} \mathrm{C}$ dengan kecepatan $3^{\circ} \mathrm{C} /$ menit. Helium digunakan sebagai gas pembawa dengan kecepatan $1 \mathrm{~mL} / \mathrm{menit}$. Sampel $(1 \mu \mathrm{L})$ disuntikkan dengan metode splitless. Kolom dihubungkan dengan Mass Spektra dan sniffing port (GC Olfactometer) yang dilengkapi dengan saluran dan diujungnya terdapat corong gelas. Linier Retention Indices (LRI) masing-masing peak dihitung berdasarkan data waktu retensi $n$-alkana standar ( $\mathrm{C}_{9}$ $\mathrm{C}_{22}$ ) yang disuntikkan pada kondisi yang sama dengan kondisi penyuntikkan sampel. Identifikasi komponen volatil dilakukan dengan mencocokkan spektrum massa dari komponen target dengan spektrum massa referensi GC-MS. Setelah itu, nilai LRI komponen target dibandingkan dengan nilai LRI dari referensi. Untuk identifikasi komoponen menggunakan NIST.

Komponen aroma diidentifikasi dengan NIF. Proses sniffing (menghirup langsung dari aliran gas kromatografi) dilakukan di dalam ruangan bersuhu $22^{\circ} \mathrm{C}$ dengan enam orang panelis tidak terlatih, dengan dua kali ulangan. Metode ini tidak perlu menggunakan sniffer (manusia sebagai detektor) ahli (Owusu, 2011). Setiap sniffing dilaksanakan selama 32 menit dari keseluruhan injeksi 70 menit.

\section{Uji deskriptif (Meilgaard et al. 1999)}

Uji sensori deskriptif dilakukan dengan metode kualitatif dan kuantitatif oleh enam orang panelis terlatih. Pelatihan panelis dilakukan dengan uji rating dan rangking dengan menggunakan flavor referensi dan standar rasa (dilakukan sebanyak 48 kali pertemuan). Metode kualitatif dilakukan dengan teknik focus group, (grup fokus) sedangkan metode kuantitatif dilakukan 
dengan metode QDA. Panelis memberikan penilaian terhadap profil sensori dari sampel dengan skala garis tidak terstruktur yang memiliki panjang $15 \mathrm{~cm}$, dengan nilai skala 0 (terendah) dan 100 (tertinggi). Atribut sensori aroma yang diuji adalah kacang (nutty), asam (acid), karamel (caramel), tanah (earthy), dan cokelat (chocolate) sedangkan atribut sensori rasanya adalah sepat (astringency), pahit (bitterness) dan asam (acidity).

Ke empat sampel pasta kakao disajikan satu per satu untuk menghindari bias saat penilaian. Pasta kakao disajikan pada suhu $40-60^{\circ} \mathrm{C}$, tanpa penambahan gula. Untuk uji rasa, panelis diminta menilai pasta kakao dengan meletakkan pasta kakao sekitar $2 \mathrm{~g}$ pada seujung sendok plastik kecil pada bagian belakang lidah, kemudian diratakan pada permukaaan lidah dengan sendok bagian belakang, lalu dirasakan dan ditelan. Pada setiap pergantian sampel, panelis diberi air minum dan biskuit tawar (crakers) untuk menetralkan indra pengecap panelis sehingga tidak terjadi bias selama penilaian sampel yang berbeda. Untuk uji aroma, panelis diminta untuk menghirup aroma pasta kakao selama 5 detik dan dinetralkan dengan aroma kopi (Reed, 2010).

Hasil yang diperoleh dari uji sensori tersebut ditampilkan dalam bentuk diagram laba-laba (spider web), serta diolah dengan bantuan analisis peubah ganda, yaitu Analisis Komponen Utama (Principal Component Analysis, PCA). Hasil PCA divisualisasikan dalam bentuk grafik biplot dengan perangkat lunak Unscrembler (CAMO Software, Amerika Serikat).

\section{Uji kesukaan (Meilgaard et al. 1999)}

Uji kesukaan (hedonik) dilakukan oleh 70 orang panelis tidak terlatih. Atribut sensori yang dinilai adalah warna, aroma, rasa, aftertaste dan penerimaan secara keseluruhan. Metode uji kesukaan menggunakan skala hedonik 1-7, dimana nilai 7 sangat suka dan nilai 1 sangat tidak suka. Data hasil uji kesukaan dianalisis sidik ragamnya pada selang kepercayaan 95\%, dengan program SPSS (IBM Corporation, Amerika Serikat) seperti diuraikan oleh Nurtama (2006). Cara penyiapan sampel dan pengujian rasa dan aroma oleh panelis sama seperti pada uji deskriptif.

\section{Uji rangking (Meilgaard et al. 1999)}

Penilaian pada uji rangking dilakukan terhadap mutu produk untuk keseluruhan parameter mutu sensori, dimana urutan pertama selalu menyatakan tingkat kesukaan sensori tertinggi dan urutan selanjutnya menunjukkan tingkat yang makin rendah. Jumlah panelis yang terlibat pada uji rangking adalah 59 orang panelis tidak terlatih. Penyajian sampel pada uji rangking dilakukan secara bersamaan dan disediakan air minum sebagai penetral indera pengecap. Cara penyiapan sampel dan pengujian rasa dan aroma oleh panelis sama seperti pada uj deskriptif.

\section{HASIL DAN PEMBAHASAN}

\section{Komponen aroma pasta kakao}

Sejumlah 28 komponen aroma dapat terdeteksi pada keempat pasta kakao yang dianalis dengan menggunakan GC-MS (Tabel 1). Ke empat pasta kakao memiliki profil aroma yang berbeda. Jumlah komponen volatil pada masing-masing pasta kakao dari Jawa Timur, Bali, Sulawesi Selatan dan Ghana secara berturut-turut adalah 21, 19, 22 dan 18 komponen volatil.

Komponen aroma yang paling dominan yang terdapat pada ke empat pasta kakao adalah asam asetat, yaitu sebesar 338.17 ppm; 191.51 ppm; 51.50 ppm dan 8.46 ppm masingmasing pada pasta kakao Ghana, Jawa Timur, Sulawesi Selatan dan Bali. Jumlah komponen asam asetat tertinggi pada pasta kakao Ghana dan Jawa Timur. Konsentrasi asam asetat yang tinggi dapat merusak mutu produk kakao (Brito et al. 2000). Tingginya asam asetat tersebut diduga dihasilkan oleh bakteri asam asetat selama proses fermentasi biji kakao. Hal ini sesuai dengan Schwan dan Wheals (2004) yang menyatakan bahwa bakteri asam laktat dan kamir merupakan mikroorganisme yang berperan dalam proses fermentasi kakao.

Komponen lain yang terdapat pada ke empat pasta kakao ialah 2.3.5.6 tetrametilpirazin. 2.3.5.6 Tetrametilpirazin merupakan komponen pirazin yang sangat berpengaruh dalam memberikan sensasi aroma cokelat yang diinginkan dalam pasta kakao (Perego et al. 2004). Komponen ini cukup dominan pada pasta kakao Jawa Timur (69.98 ppm) dan Sulawesi Selatan (12.28 ppm), namun kurang dominan pada pasta kakao Bali (2.21 ppm) dan Ghana (3.59 ppm). Komponen tetrametilpirazin pada pasta kakao Ghana yang diperoleh ini lebih rendah dibandingkan dengan hasil penelitian Perego et al. (2004) yaitu $13.91 \mathrm{ppm}$.

Secara umum jumlah kandungan komponen-komponen aroma yang terkandung pasta kakao Ghana lebih besar (779.52 ppm) dibandingkan ketiga jenis pasta kakao Indonesia (Tabel 1). Hal inilah yang mungkin menyebabkan pasta kakao Ghana sering dianggap sebagai pasta kakao terbaik (Wahyudi et al. 2008). Namun bila dicermati lebih jauh jumlah komponen volatil bukanlah penentu mutu flavor mengingat tidak semua komponen volatil memiliki sensori aroma dan berperan sebagai komponen aroma aktif pada pasta kakao. Selain itu terdapat berapa komponen yang terdeteksi lebih banyak pada pasta kakao Indonesia dan bahkan ada komponen yang tidak ditemui dalam kakao Ghana, misalnya 3-hidroksi-2 butanon yang memiliki aroma caramel dan Linalool memiliki yang aroma daun hijau manis (sweet green). Oleh karenanya perlu pengamatan lebih jauh terhadap komponen aroma aktif dari pasta-pasta kakao yang diteliti ini.

\section{Komponen aroma aktif pada pasta kakao}

Hasil identifikasi aroma aktif dengan GC-MS/O dapat dilihat pada Gambar 1. Komponen aroma aktif adalah komponen volatil yang berkontribusi pada sensori dan memberikan karakteristik flavor pada produk tersebut (Wijaya et al. 2005). Pasta kakao Ghana memiliki aroma cokelat (chocolate), kakao (cocoa), kacang (nutty), krim (creamy), tanah (earthy), tengik (rancid), panggang (roasted), pahit (bitter), segar (fresh), manis (sweet), bunga (floral), asam (sour) dan asam fermentasi (acid fermented). Aroma nutty dan chocolate diduga merupakan kontribusi dari komponen 2.3.5-trimetilpirazin, 3-etil-2.5dimetilpirazin, 2-etil-3.5-dimetilpirazin,2.3.5.6- tetrametilpirazin dan 2.3-dietil-5-metilpirazin. 
Tabel 1. Hasil Identifikasi komponen aroma pasta kakao dari Jawa Timur, Bali, Sulawesi Selatan dan Ghana

\begin{tabular}{|c|c|c|c|c|c|c|c|}
\hline \multirow{2}{*}{ Komponen } & \multirow{2}{*}{ RT } & \multirow{2}{*}{$\begin{array}{l}\text { LRI } \\
\exp \end{array}$} & \multirow{2}{*}{$\begin{array}{l}\text { LRI } \\
\text { ref }\end{array}$} & \multicolumn{4}{|c|}{ Konsentrasi (ppm) } \\
\hline & & & & Jawa Timur & Bali & Sulawesi Selatan & Ghana \\
\hline 3-Hidroksi-2-butanon & 27.51 & 1255 & $1273^{a}$ & 8.23 & 0.86 & 1.37 & - \\
\hline 1-Metilpiperidin & 29.67 & 1296 & & 4.09 & - & - & - \\
\hline 2.6-Dimetilpirazin & 29.30 & 1289 & $1308^{c}$ & 2.46 & - & 0.40 & - \\
\hline \multirow[t]{2}{*}{ 2.3-Dimetilpirazin } & 30.48 & 1312 & $1315^{d}$ & - & - & 0.60 & - \\
\hline & & & $1326 \mathrm{e}$ & & & & \\
\hline 2-Isopropil-5-metil-2-heksenal & 30.75 & 1328 & & 21.34 & 1.31 & 4.73 & 37.21 \\
\hline \multirow[t]{2}{*}{ 2.3.5-Trimetilpirazin } & 33.05 & 1367 & $1387^{d}$ & 25.99 & 0.63 & 3.90 & 26.29 \\
\hline & & & $1394^{4}$ & & & & \\
\hline \multirow[t]{2}{*}{ 3-Etil-2.5-dimetilpirazin } & 34.83 & 1405 & $1402^{9}$ & - & 0.25 & 1.27 & 18.62 \\
\hline & & & $1429^{d}$ & & & & \\
\hline 2-Etil-3-metil pirazin & 34.51 & 1398 & $1379 \mathrm{e}$ & 6.91 & - & - & - \\
\hline Asam asetat & 35.03 & 1410 & 14109 & 191.51 & 8.46 & 51.50 & 338.17 \\
\hline \multirow[t]{2}{*}{ 2-Etil-3.5-dimetilpirazin } & 35.49 & 1421 & $1446^{f}$ & 8.00 & 0.31 & 1.87 & 98.58 \\
\hline & & & $1449 \mathrm{e}$ & & & & \\
\hline 3.5-Dietil-2-metilpirazin & 36.39 & 1423 & $1474^{k}$ & 2.05 & - & - & - \\
\hline Tetrametilpirazin & 36.04 & 1433 & $1484 j$ & 69.98 & 2.21 & 12.28 & 3.59 \\
\hline 2.3-Dietil-5-metilpirazin & 37.61 & 1472 & $1476^{4}$ & 7.26 & 0.29 & 1.34 & 4.17 \\
\hline Benzaldehid & 38.19 & 1485 & $1458^{\mathrm{e}}$ & 3.58 & - & 0.75 & - \\
\hline Linalool & 38.85 & 1501 & $1540^{e}$ & - & 0.32 & 0.60 & - \\
\hline 2.3-Butanediol & 39.98 & 1531 & $1541 \mathrm{e}$ & 29.95 & 1.47 & 9.48 & 5.58 \\
\hline 1.3-Metoksipropil asetat & 39.51 & 1509 & & - & - & 2.28 & - \\
\hline 3-isobutil-2-metoksipirazin & 39.53 & 1519 & $1517 \mathrm{e}$ & 24.70 & - & - & - \\
\hline 2-asam metilpropanoat & 39.67 & 1523 & $1562^{\mathrm{h}}$ & - & 0.85 & 2.28 & 28.58 \\
\hline Dehidro-2(3H)-furanon & 42.2 & 1592 & & 2.71 & 0.16 & 0.54 & 2.75 \\
\hline 3-metil-asam butanoat & 43.41 & 1623 & $1620^{\mathrm{h}}$ & 54.68 & 1.67 & 3.51 & 99.44 \\
\hline \multirow[t]{2}{*}{ Etil fenil asetat } & 47.61 & 1721 & $1720^{\mathrm{h}}$ & 5.04 & 0.17 & 0.28 & 10.01 \\
\hline & & & $1748^{f}$ & & & & \\
\hline 2-Fenetil asetat & 48.61 & 1772 & $1804^{\mathrm{h}}$ & 7.13 & 0.32 & 1.39 & 27.66 \\
\hline 1-Asam heksanoat & 49.43 & 1796 & & - & - & - & 7.74 \\
\hline 2-Feniletanol & 51.69 & 1883 & 18939 & 7.54 & 0.57 & 2.13 & 47.33 \\
\hline (2Z)-2-fenil-2-butenal & 52.24 & 1887 & & 2.76 & 0.12 & 0.37 & 7.12 \\
\hline 5-Metil-2-fenil-2-heksenal & 56.53 & 2026 & & 4.40 & 0.29 & 0.84 & 12.92 \\
\hline 3.5-Dihidroksi-6-metil-2.3-dihidro-4H-piran-4-on & 62.35 & 2094 & & - & 0.12 & - & 3.76 \\
\hline Persen teridentifikasi (\%) & & & & $55.26 \%$ & $50.0 \%$ & $56.4 \%$ & $50.0 \%$ \\
\hline Total (ppm) & & & & 490.31 & 20.4 & 103.71 & 779.52 \\
\hline
\end{tabular}

Exp: experiment. Ref: reference; aAvsar et al. (2010), bRanau et al. (2005), ' ${ }^{\circ}$ Mebazaa et al. (2011), dMebazaa et al. (2009), e Lasekan et al. (2012), ${ }^{\mathrm{f}}$ Frauendorfer dan Schieberle (2006), gJarunrattanasri (2004), ${ }^{\mathrm{h}}$ yychlik dan Bosset (2001)

Pasta kakao Jawa timur memiliki komponen yang memberikan aroma krim (creamy), karamel (caramel), cokelat (chocolate), kakao (cocoa), kacang (nutty), tanah (earthy), biji kopi (coffee bean), tengik (rancid), panggang (roasted), segar (fresh), bunga (floral) dan asam fermentasi (acid fermented). Dibandingkan dengan pasta kakao Ghana, pasta kakao dari Jawa Timur memiliki komponen aroma creamy, caramel dan coffee bean yang tidak dimiliki pasta kakao Ghana. Komponen nutty di pasta kakao Jawa Timur diduga diperoleh dari komponen volatil 2.6-dimetilpirazin, 2-etil-3-metilpirazin, 3.5-dietil-2metilpirazin, 3-isobutil-2-metoksipirazin yang tidak terdapat pada pasta kakao Ghana dan pasta kakao lainnya. Pasta kakao Bali memiliki komponen yang memberikan aroma creamy, caramel, chocolate, cocoa, nutty, earthy, sweet, bitter, rancid, roasted, fresh, floral dan acid fermented. Aroma sweet dari komponen etil fenilasetat dan 2-fenilasetat diduga merupakan komponen aroma kunci pada pasta kakao Bali. Komponen-komponen ini juga merupakan komponen kunci pada pasta kakao Ghana seperti dilaporkan oleh Afoakwa et al. (2008) dan Owusu et al. (2011). Akan tetapi dibandingkan dengan pasta kakao Ghana, pasta kakao Bali memiliki komponen dengan aroma creamy dan caramel yang sangat kuat. Pasta kakao Sulawesi Selatan memiliki komponenn yang memberikan aroma creamy, caramel, chocolate, cocoa, nutty, earthy, coffee bean, bitter, sweet, sweet green, rancid, roasted, fresh, floral dan acid fermented. Pasta kakao Sulawesi Selatan memiliki aroma sweet green yang mungkin merupakan kontribusi dari komponen volatil linalool. Aroma sweet green ini selain tidak dimiliki oleh pasta kakao Ghana, juga tidak dimiliki oleh pasta kakao lainnya. 


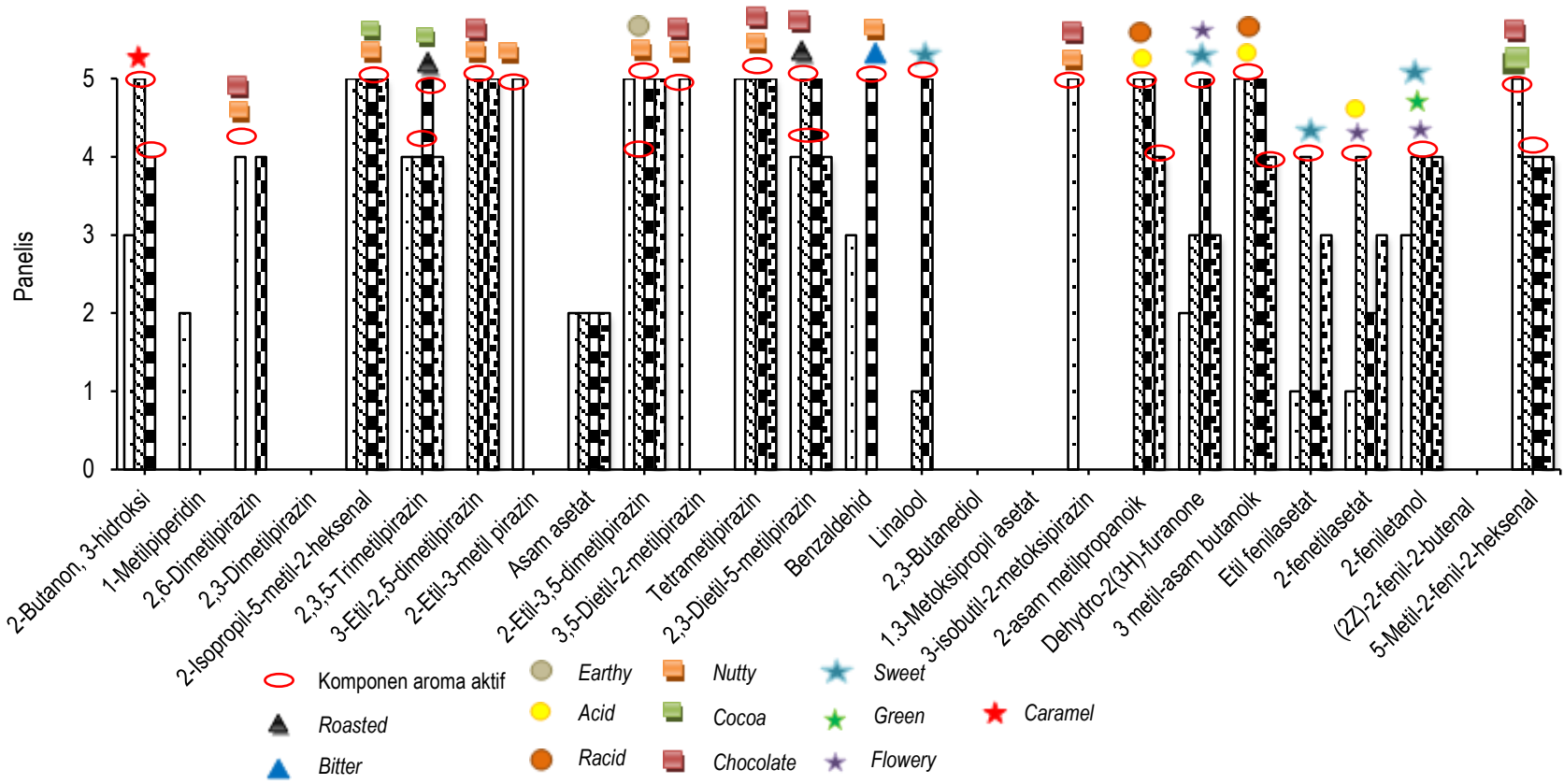

Gambar 1. Komponen aroma aktif pada pasta kakao dari Jawa Timur ( $\square)$, Sulawesi Selatan $(\boldsymbol{\Xi})$, Bali dan Ghana $(\boldsymbol{\Xi})$ yang dapat dideteksi oleh panelis pada analisis GC-O

Berdasarkan hasil analisis GC-MS/O diketahui bahwa profil komponen aroma kunci pada pasta-pasta kakao dari Indonesia berbeda dengan pasta kakao dari Ghana. Pasta kakao Jawa Timur memiliki lebih banyak komponen aroma kunci yang memberikan sensasi aroma chocolate, sedangkan pasta kakao Bali mempunyai komponen dengan aroma caramel yang kuat, sementara pasta kakao Sulawesi Selatan memiliki komponen aroma kunci sweet green.

\section{Profil sensori aroma dan rasa pasta kakao}

Evaluasi sensori terhadap profil ke empat jenis pasta kakao dilakukan dengan metode QDA. Metode ini dipilih berdasarkan pertimbangan kuantifikasi atribut yang dapat terukur. Berdasarkan focus group dengan 6 orang panelis terlatih (3 wanita, 3 pria) telah dipilih 8 atribut penting pada pasta kakao yaitu atribut aroma yang meliputi nutty, chocolate, acid, caramel, earthy dan atribut sensori rasa yang meliputi pahit, sepat dan asam. Atribut terpilih selaras dengan hasil analisis GC-MS/O yang menunjukkan adanya sensori dari komponen aroma kunci yang terdeteksi seperti aroma nutty dari senyawa trimetilpirazin, chocolate dari senyawa tetrametilpirazin, acid dari senyawa 3-metil-asam butanoat, caramel dari 3 hidroksi-2 butanon, dan earthy dari senyawa 2-etil-3.5-dimetilpirazin.

Hasil uji deskripsi QDA terhadap atribut aroma dan rasa dapat dilihat pada Gambar 2. Terlihat bahwa ketiga pasta kakao Indonesia dan pasta kakao Ghana memiliki profil sensori yang berbeda satu sama lain. Pasta kakao Jawa Timur dicirikan oleh atribut rasa pahit, rasa asam dan rasa sepat yang kuat dibandingkan dengan pasta kakao Ghana dan kedua pasta kakao lainnya. Pasta kakao Jawa Timur memiliki aroma chocolate yang kuat dengan aroma acid yang lemah. Aroma chocolate yang kuat ini dapat disebabkan oleh tingginya kandungan komponen tetrametilpirazin dan trimetilpirazin (lihat Tabel 1).
Pasta kakao Bali memiliki intensitas rasa sepat tinggi yang mirip dengan pasta kakao Jawa Timur, namun memiliki intensitas rasa pahit dan asam yang lebih lemah. Rasa pahit merupakan rasa khas dari cokelat, yang berasal dari komponen-komponen alkaloid seperti theobromine dan caffeine, komponen fenolik, pirazin, beberapa peptida dan asam amino bebas (Owusu et al. 2011). Pasta kakao Bali memiliki aroma caramel paling tinggi denganaroma earthy yang paling rendah. Hal ini merupakan kombinasi profil sensori yang menguntungkan. Pasta kakao Sulawesi Selatan memiliki kemiripan profil aroma dan rasa dengan pasta kakao pembanding yaitu kakao Ghana. Pasta kakao Ghana memiliki aroma earthy yang tinggi. Tingginya intensitas aroma earthy dapat dipahami karena hasil analisis secara semi-kuantitatif pada Tabel 1 juga menunjukkan bahwa komponen 2 etil-3.5-dimetilpirazin yang memberikan aroma earthy pada kedua pasta yang konsentrasinya lebih tinggi dibanding pasta yang lain. Hasil GC-MS/O seperti ditunjukkan dalam Gambar 1 memberikan indikasi yang sama. Selain aroma earthy, pasta kakao Sulawesi Selatan dicirikan dengan aroma acid yang tinggi.

Hasil PCA yang memperlihatkan keterkaitan antar atribut aroma dan rasa pasta kakao dinyatakan dalam grafik biplot (Gambar 3). Hasil score dari ke empat pasta kakao menunjukkan bahwa pasta kakao Bali dan Jawa Timur memiliki kedekatan karena keduanya berada pada kuadran nilai positif, sedangkan pasta kakao Sulawesi Selatan lebih dekat Ghana karena bersama pada kuadran nilai negatif. Dari hasil plot score terlihat kembali bahwa dari ketiga jenis kakao asal Indonesia, yang memiliki kedekatan dengan kakao Ghana (pembanding) adalah kakao Sulawesi Selatan. Selain letak keduanya di kuadran yang sama, jarak antar titik Ghana-Sulawesi Selatan lebih dekat daripada Ghana-Jawa Timur dan Ghana-Bali. Seperti telah dijelaskan sebelumnya, kedekatan profil pasta kakao Sulawesi Selatan dan Ghana pada PCA ini juga dapat dilihat pada hasil 
QDA (Gambar 2) yang memperlihatkan profil jaring laba-laba pasta Sulawesi Selatan lebih mirip dengan pasta Ghana.

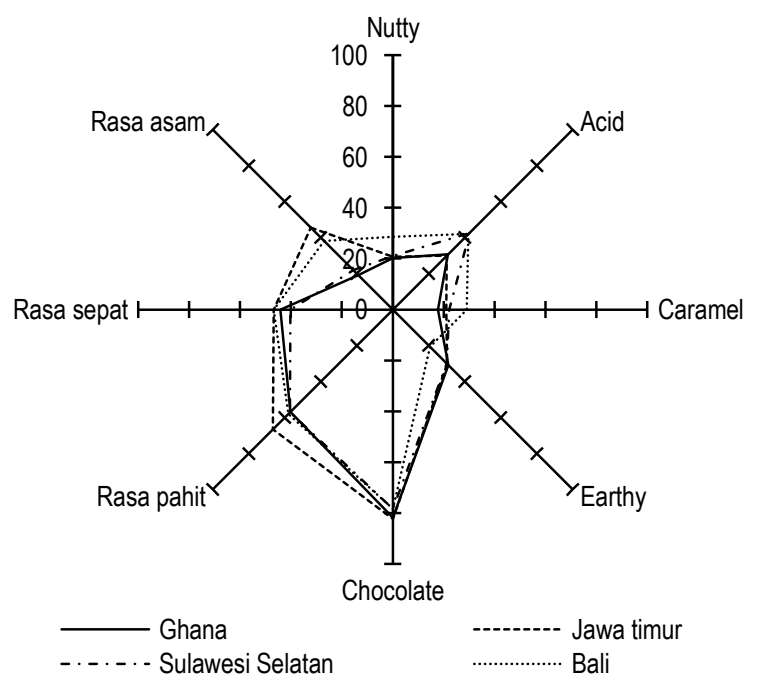

Gambar 2. Diagram profil aroma dan rasa pasta kakao dari Jawa Timur, Bali, Sulawesi Selatan dan Ghana

Gambar 3 juga menunjukkan bahwa atribut aroma caramel berkorelasi positif dengan aroma nutty. Rasa asam, pahit dan sepat memiliki korelasi positif dengan aroma chocolate. Aroma acid dan earthy berkorelasi negatif terhadap aroma caramel, nutty, chocolate dan rasa asam, pahit, sepat. Berdasarkan hasil PCA diketahui bahwa seluruh pasta kakao berada pada kuadran yang berbeda, dan tidak ada profil sensori pasta kakao yang saling berdekatan. Hal ini dapat memperlihatkan bahwa ke empat pasta kakao memiliki karakteristik yang khas.

Hasil PCA ini memperlihatkan bahwa atribut aroma nutty dan caramel lebih mencirikan aroma yang dominan pada pasta kakao Bali (kuadran I) dan chocolate lebih mencirikan aroma yang dominan pada pasta kakao Jawa Timur (kuadran II) tetapi secara keseluruhan atribut aroma nutty, caramel dan chocolate dapat menjadi aroma yang mencirikan pasta kakao Bali dan Jawa Timur karena atribut aroma tersebut pada kuadran positif. Perbedaan yang terlihat pada masing-masing atribut aroma adalah intensitas aromanya.

Pasta kakao Sulawesi Selatan (kuadran IV) lebih dicirikan dengan aroma acid walaupun tidak terlalu dominan. Pasta kakao pembanding (Ghana) terdapat pada kuadran III dengan penciri aroma earthy. Pada atribut rasa nampak bahwa pasta kakao Jawa Timur kaya memiliki atribut rasa pahit dan sepat yang dominan dibandingkan dengan semua jenis pasta kakao lainnya. Pasta kakao Sulawesi Selatan tidak memiliki ciri aroma yang dominan, namun memiliki profil aroma yang mirip dengan pasta kakao Ghana.

Pasta kakao Ghana pada penelitian ini memiliki aroma dominan earthy. Hal ini berbeda dari laproran Afoakwa et al. (2008) yang menyatakan bahwa pasta kakao Ghana memiliki aroma dominan aroma dasar kakao yang kuat (strong basic cocoa) dan aroma buah (fruity). Fenomena yang menyimpang ini diduga dikarenakan kualitas biji kakao yang diperoleh pada penelitian disini berada pada mutu 3, bukan mutu 1 dan 2 (mutu sesuai standar SNI kakao tahun 2008) (BSN, 2008), sehingga ada kemungkinan biji kakao telah tertumbuhi jamur sehingga aroma pasta kakao Ghana yang dihasilkan pada penelitian ini memberikan aroma earthy (tanah). Kemungkinan lain adalah meskipun dari daerah Ghana, namun kondisi di setiap daerah di Ghana pun dapat berbeda pula yang berkontribusi pada perbedaan mutu kakao yang dihasilkan dan dalam penelitian ini terlihat bahwa mutu aroma dari pasta kakao Indonesia lebih unggul. Perbedaan aroma dapat disebabkan pada variasi komposisi biji kakao dari jenis tanaman, lokasi tumbuh dan perbedaan perlakuan petani (Afoakwa et al. 2008). Perlu dilakukan pengujian lebih lanjut dengan menggunakan beberapa jenis kakao Ghana dengan mutu unggul sebagai referensi.

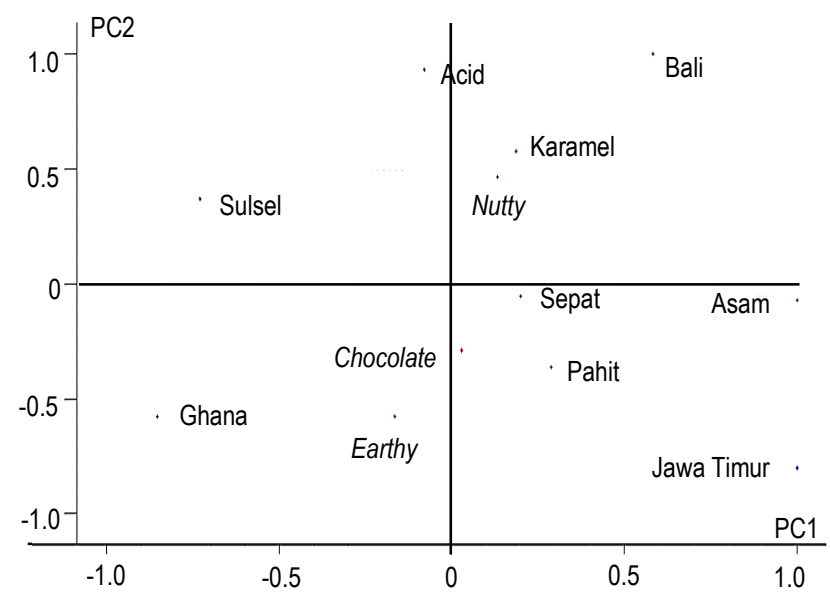

Result 2, X-expl: $63 \%, 31 \%$

Gambar 3. Hasil biplot PCA (score dan x-loading) atribut aroma dan rasa pasta kakao Jawa Timur, Bali, Sulawesi Selatan dan Ghana

\section{Mutu kesukaan dan rangking}

Hasil uji kesukaan terhadap atribut warna, aroma, rasa, tekstur, aftertaste dan penerimaan secara keseluruhan dari pasta kakao yang diperlihatkan pada Gambar 4. Pada atribut warna nampak bahwa pasta kakao dari Jawa Timur dan Bali paling disukai. Pasta kakao Jawa Timur memiliki warna kuning kecokelatan lebih kuat. Penerimaan kesukaan terhadap warna pasta kakao Jawa Timur tidak berbeda nyata dengan warna kakao Bali (Gambar 5). Pasta kakao Ghana memiliki warna cokelat lebih terang seperti halnya warna kakao Sulawesi yang juga kurang disukai.

Tingkat penerimaan panelis terhadap atribut aroma pasta kakao Jawa Timur paling tinggi dan berbeda nyata dibandingkan dengan pasta kakao Bali, Sulawesi Selatan dan Ghana. Pasta kakao Sulawesi Selatan mempunyai tingkat penerimaan yang sama dengan pasta kakao Ghana. Kandungan komponen volatil tetrametilpirazin pada pasta kakao Jawa Timur paling tinggi. Komponen ini dideskripsikan sebagai aroma nutty, chocolate. Hal inilah yang diduga menyebabkan aroma cokelat pasta kakao Jawa Timur lebih kuat dan lebih disukai panelis. Aroma pasta kakao Bali juga disukai oleh panelis dibandingkan dengan aroma pasta kakao Sulawesi Selatan dan kakao pem- 
banding Ghana. Untuk atribut rasa, terlihat bahwa pasta kakao Bali memiliki tingkat penerimaan yang nyata lebih tinggi dibandingkan Jawa Timur. Pasta kakao Sulawesi Selatan dan Ghana mempunyai tingkat penerimaan rasa yang lebih rendah dan keduanya tidak berbeda nyata. Penerimaan panelis terhadap atribut aftertaste memiliki kecenderungan yang sama pada seluruh pasta kakao. Senyawa yang mempunyai efek aftertaste adalah komponen tanin atau polifenol (Misnawi et al. 2002).

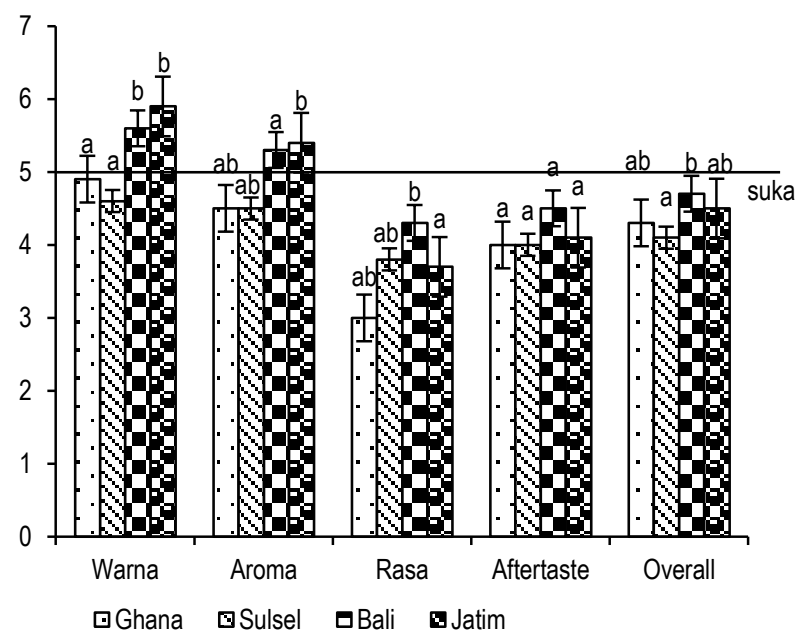

Gambar 4. Hasil penilaian sensori ke empat pasta kakao pada uj hedonik. Skor kesukaan 7 = sangat suka, skor kesukaan 1 = sangat tidak suka. Nilai yang diikuti oleh huruf yang berbeda menunjukkan berbeda nyata $(p<0.05)$

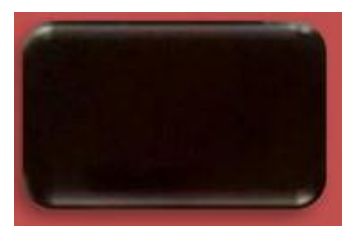

a
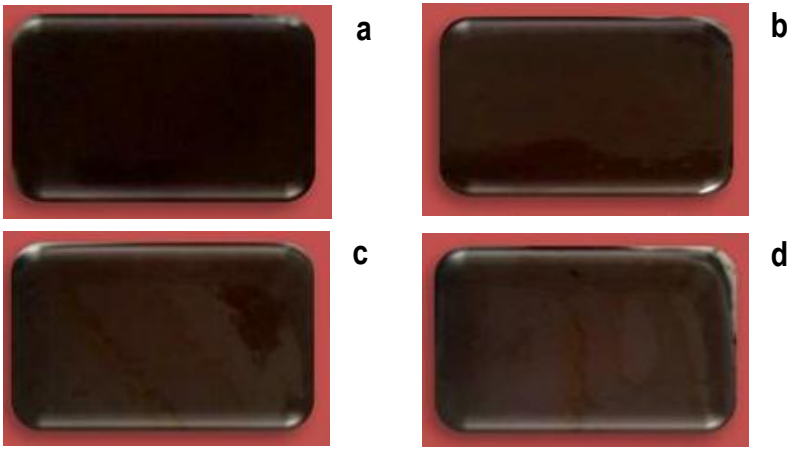

Gambar 5. Warna pasta kakao (a) Jawa Timur; (b) Bali; (c) Sulawesi Selatan; (d) Ghana dengan uji lanjut Duncan

Berdasarkan hasil uji hedonik bahwa secara keseluruhan, penerimaan pasta kakao Bali sedikit lebih tinggi dari pasta kakao Jawa Timur yaitu pada kisaran agak suka (Bali 4.7 dan Jawa Timur 4.5 dari skala 7) berbeda nyata dengan pasta kakao Sulawesi Selatan dan pasta kakao Ghana sebagai pembanding. Tingkat kesukaan kakao Ghana adalah 4.3 dan Sulawesi Selatan pada 4.1. Pasta kakao Bali sedikit lebih unggul secara kesuluruhan dari pasta kakao Jawa Timur mungkin disebabkan oleh keunggulan dari segi rasa. Uji rangking memperkuat hasil pengujian kesukaan pada tiap-tiap atribut yang dinilai (Tabel 2). Pasta kakao dari Bali dan Jawa Timur berada pada urutan pertama, selanjutnya pasta kakao
Ghana dan Sulawesi Selatan. Pasta kakao Bali menempati rangking tertinggi dan secara berurutan diikuti oleh Jawa Timur, Ghana dan Sulawesi Selatan. Pada uji rangking ini juga terlihat bahwa nilai rangking antara pasta kakao Bali dan Jawa Timur tidak berbeda jauh. Pola yang serupa dengan hasil uji kesukaan bahwa pasta kakao Jawa Timur berdekatan dengan pasta kakao Bali. Pasta kakao Jawa Timur memiliki keunggulan penerimaan dalam hal warna namun memiliki kelemahan dalam tingkat penerimaan rasa, sedangkan pasta kakao Bali memiliki keunggulan penerimaan pada atribut rasa dan overall.

Dari hasil PCA dapat dilihat korelasi pasta kakao yang disukai panelis dengan atribut yang mempengaruhi aroma khas cokelat. Pasta kakao Bali yang mendapatkan rangking pertama memiliki aroma nutty dan caramel, pasta kakao Jawa Timur pada peringkat kedua memilki aroma chocolate dan rasa dominan pahit, sepat dan asam. Pasta kakao Ghana mendapatkan rangking ketiga memiliki aroma earthy dan pasta kakao Sulawesi Selatan pada peringkat ke empat memiliki aroma dominan asam. Menurut Misnawi et al. (2002), pada biji kakao yang kurang fermentasi tidak terbentuk aroma cokelat ketika proses penyangraian. Hal ini dapat membuktikan bahwa pasta kakao Indonesia, terutama pada pasta kakao Bali dan Jawa Timur jika dilakukan fermentasi yang cukup (5-6 hari) dan proses yang benar menghasilkan kualitas aroma dan rasa yang baik. Pada pasta kakao Ghana yang kurang disukai panelis diduga karena pada proses penyimpanan yang terlalu lama, sehingga menimbulkan aroma earthy.

$\underline{\text { Tabel 2. Hasil uji rangking pasta kakao }}$

\begin{tabular}{ccc}
\hline Rangking & Nilai & Pasta Kakao \\
\hline 1 & $2.1 \pm 1.1$ & Bali \\
2 & $2.1 \pm 0.8$ & Jawa Timur \\
3 & $2.8 \pm 1.0$ & Ghana \\
4 & $3.0 \pm 1.1$ & Sulawesi Selatan \\
\hline
\end{tabular}

Secara keseluruhan hasil analisis menunjukkan keselarasan bahwa profil sensori pasta kakao unggulan dari beberapa Indonesia memiliki keunggulan dibandingkan dengan pasta kakao Ghana yang digunakan dalam penelitian. Hasil uji penerimaan juga menunjukkan bahwa pasta kakao Bali dan Jawa timur lebih disukai dari kakao pembanding. Keunggulan pada mutu aroma dan warna merupakan atribut-atribut yang berkontribusi. Perlu dilakukan pengukuran lebih lanjut dengan menggunakan kakao Ghana dengan tingkat kesegaran yang sama karena pada kakao Ghana yang digunakan dalam penelitian ini diduga telah mengalami penyimpanan yang terlalu lama, sehingga menimbulkan aroma earthy.

\section{KESIMPULAN}

Pasta kakao dari Jawa Timur, Bali dan Sulawesi Selatan memiliki komponen aroma aktif yang berbeda dibandingkan pasta kakao Ghana. Pasta kakao Jawa Timur memiliki sensori aroma aktif yaitu aroma chocolate (tetrametilpirazin), dengan dominan rasa pahit, sepat dan asam. Pasta kakao Bali memiliki aroma aktif caramel (3 hidroksi-2 butanon) dan nutty (trimetilpirazin). Pasta kakao pasta kakao Sulawesi Selatan 
memiliki sensori aroma aktif yang dominan yaitu acid (3-metilasam butanoat). Adapunpasta kakao Ghana memiliki aroma aktif yang dominan earthy (2 etil-3,5-dimetilpirazin). Ketiga pasta kakao memiliki profil sensori yang berbeda satu sama lain. Profil sensori Sulawesi Selatan memiliki profil yang paling mirip dengan pasta kakao pembanding Ghana.

Perbedaan profil aroma ini berkontribusi pada perbedaan penerimaan panelis, Tingkat kesukaan panelis terhadap pasta kakao Bali sedikit lebih tinggi dari pasta kakao Jawa Timur, diikuti dengan pasta kakao Ghana dan Sulawesi Selatan. Pasta kakao Bali mendapatkan rangking pertama dengan ciri khas aroma nutty dan caramel, pasta kakao Jawa Timur pada peringkat kedua memilki ciri khas aroma chocolate dan rasa dominan pahit, sepat dan asam. Pada rangking ketiga adalah pasta kakao Ghana yang kurang disukai panelis dengan aroma earthy yang dominan. Pasta kakao Sulawesi Selatan pada peringkat ke empat memiliki aroma asam yang dominan. Pasta kakao Indonesia, terutama pada pasta kakao Bali dan Jawa Timur, dapat memberikan kualitas aroma dan rasa yang baik.

\section{UCAPAN TERIMA KASIH}

Penulis mengucapkan terima kasih kepada Direktur Pusat Penelitian Kopi dan Kakao, Jember, Indonesia yang telah memberikan bantuan dana sehingga penelitian ini dapat dilaksanakan.

\section{DAFTAR PUSTAKA}

Afoakwa EO, Paterson A, Fowler M, Ryan A. 2008. Flavor formation and character in cocoa and chocolate: A Critical Review. Crit Rev Food Sci Nutr 48: 840-857. DOI: 10.1080/ 10408390701719272.

Avsar YK, Yuceer YK, Drake MA, Singht MK, Yoon Y, Cadwallader KR. 2004. Characterization of nutty flavor in cheedar cheese. J Dairy Sci 87: 1999-2010.

Brito ES, Garcia NHP, Gallao ML, Cortelezzo AL, Fevereiro PS, Braga MR. 2000. Structural and chaemical changes in cocoa during fermentation, drying, roasting. J Agr Food Chem 81: 281-288. DOI: 10.1002/1097-0010(20010115)81: 2<281::AID-JS FA808>3.0.CO;2-B.

[BSN] Badan Standarisasi Nasional. 2008. Biji Kakao. 01-23232008. Jakarta.

Dinas Perkebunan Provinsi Bali. 2012. Potensi kakao di Bali. statistik perkebunan Bali, Dinas perkebunan Provinsi Bali.http://regionalinvestment.bkpm.go.id. [19 Februari 2013].

Direktorat Jenderal Perkebunan. 2012. Cokelatku, budayaku, Indonesia ku. http://ditjenbun.deptan.go.id. [19 Februari 2013].
Frauendorfer F, Schieberle P. 2006. Identification of the key aroma compounds in cocoa powder based on molecular sensory correlations. J Agr Food Chem 54: 5521-5529. DOI: 10.1021/jf060728k.

[ICCO] International Cocoa Organization. 2013. Quarterly bulletin of cocoa statistics, 39 cocoa year 2012/2013. http://www.icco.org/about-us/icco-news/229-may-2013quarterly-bulletin-of-cocoa-statistics.html.

Jarunrattanasri A. 2004. Aroma Formation From Rice Bran Protein Concentrate by Acid Hydrolysis and the Maillard Reaction [Disertasi]. Thailand: Kasetsart University.

Langkong J, Ishak E, Bilang M, Muhidong J. 2011. Pemetaan lemak dari biji Kakao (Theobroma cocoaL.) di Sulawesi Selatan. http://pasca.unhas.ac.id/jurnal/files/1c968d54ed2d0 33c 105227669ae4b8b3pdf. [19 Februari 2013].

Lasekan O, Buettner A, Christbauer M. 2007. Investigation of important odorant of palm wine (Elaeis guineensis). Food Chem 105: 15-23. DOI: 10.1016/j.foodchem.2006. 12.052.

Luna F, Crouzillat D, Cirou L, Bucheli P. 2002. Chemical composition and flavor of ecuadorian cocoa liquor. J Agr Food Chem 50: 3527-3532. DOI: 10.1021/jf0116597.

Mebazaa R, Mahmoudi A, Fouchet M, Santos MD, Kamissoko F, Nefti A, Cheikh RB, Rega B, Camel V. 2009. Characterisation of volatile compounds in Tunian fenugreek seeds. France. Food Chem 115: 1326-1336. DOI: 10.1016/j. food chem.2009.01.066.

Mebazaa R, Rega B, Camel V. 2011. Analysis of human malearm sweat after characteisation of odour active compound by GC coupled to mass spectrometry and olfactometry. Food Chem 128: 227-235. DOI: 10.1016/j.food chem.2011.02.063.

Meilgaard MC, Civille GV, Carr BT. 1999. Sensory Evaluation Techniques. RC Press.CLL. Ed 3. Washington.

Misnawi, Jinap S, Bakar J, Saari N. 2002. Oxidation of polyphenols in unfermented and partly fermented cocoa beans by cocoa polyphenoloxidase and tyrosinase. J Agr Food Chem 82: 559 - 566. DOI: 10.1002/jsfa.1075.

Misnawi, Ariza. 2011. Use of gas chromatography-olfactometry in combination with solid phase micro extraction for cocoa liquor aroma analysis. J Int Food Res 18: 829-135.

Nurtama B. 2006. Pengolahan Data Uji Sensori Produk Pangan. Departemen IImu dan Teknologi Pangan Fakultas Teknologi Pertanian IPB Bogor. Bogor.

Owusu M, Petersen MA, Heimdal H. 2011. Effect of fermentation method, roasting andconching conditions on the aroma volatiles of dark chocolate. J Food Process 446456. DOI: 10.1111/j.1745-4549.2011.00602.

Perego P, Febiano B, Cavicchioli M, Borghi M. 2004. Cocoa quality and processing a study by solid phase microextraction and gas chromatography analysis of methylpyrazines. Food Bioprod Process 84: 291-297. DOI: 10.1205/fbio.82.4.291.56402. 
Ranau R, Kleeberg KK, Schegelmilch M, Streese J, Stegman R, Steinhard H. 2005. Analytical determination of the suitability of difference processes for the treatment of odorous waste gas. Waste Management 25: 908-916. DOI: 10.1016/j. wasman.2005.07.004.

Reed S. 2010. Sensory Analysis of Chocolate Liquor. Cargill Incoporate. America.

Rychlik M, Bosset JO. 2001. Flavour off-flavour compounds of Swiss gruy cheese. Int Dairy J 11: 895-901. DOI: 10.1016/ S0958-6946(01)00108-X.
Schwan RF, Wheals AE. 2004. The microbiology of cocoa fermentation and its role in chocolate quality. Crit Rev Food Sci Nutr 44: 205-221.

Wahyudi T, Panggabean TR, Pujiyanto. 2008. Panduan Lengkap Kakao. 56-105. PT. Niaga Swadaya. Jakarta.

Wijaya CH, Ulrich D, Lestari R, Schippel K, Ebert G. 2005. Identification of potent odorants in different cultivars of snake fruit [Sallaca zalacca (Gaert.) Voss] using gass chromatography-olfactometry J Agr Food Chem 53: 16371641. DOI: $10.1021 / \mathrm{jf} 048950 \mathrm{~h}$. 